\title{
Comprehensive Planning of Urban Housing in Metropolises by Focusing on Urban Integrated Management
}

\author{
Seyed Mohammadreza Talakesh ${ }^{1}$, Jamal Mohammadi ${ }^{1} \&$ Ali Zangiabadi ${ }^{1}$ \\ ${ }^{1}$ School of Geographic \& Planning Science, University of Isfahan, Isfahan, Iran \\ Correspondence: Seyed Mohammadreza Talakesh, School of Geographic \& Planning Science, University of \\ Isfahan, Isfahan, Iran. Tel: 98-91-2370-6888. E-mail: s.talakesh@yahoo.com
}

Received: April 23, 2015

Accepted: May 25, 2015

Online Published: October 13, 2015

doi:10.5539/mas.v9n13p22

URL: http://dx.doi.org/mas.v9n13p22

\begin{abstract}
Many scholars of urban studies believe that the most important factor effective on the amount of individuals' welfare is housing. Population increase of Iran and the expansion of the range of cities in Iran in recent decades cause centralization and increase in population densities in Iran and it seems that during recent years, economic policies of housing, as the interface ring for spatial planning policies of lands and urban and rural development, has been to some extent neglected by Iran's planning officials. Considering the multidimensionality of the issue of housing, for urban housing planning the intervention of different state and urban organizations is required and the lack of a comprehensive and integrated management is tangible in this issue. Regarding the domination of municipalities over internal issues of cities and also regarding geographical, political, economic and social conditions of different cities, municipalities can burden the responsibility of this issue. The objective of the present study is to investigate the problem of housing in Iran and providing an appropriate strategy for resolving this issue. Accordingly, the study, by doing library research, administering interviews and consulting state authorities and elites of housing markets and also by using the authors' scientific and executive experiences, an organizational structure was suggested for solving the housing issue. Then, by preparing questionnaires and surveying three groups (citizens, state and municipality authorities and academic specialists) this structure was evaluated using matrix QSPM and the SWOT model. Finally, by using the conducted surveys, the desired strategies were presented for improving the performance of organizational structure.
\end{abstract}

Keywords: housing planning, integrated urban management, suggested organizational structure, SWOT model

\section{Introduction}

\subsection{Housing Problem}

Housing is one of the most important and basic requirements of human beings and has a fundamental role in providing welfare for them. Many scholars of urban studies believe that the most important factors effective on the amount satisfaction and welfare of individuals residing in a zone and the style of their lives are housing and environmental conditions of the zone and living in an unfavorable housing condition (whether in terms of quality or quantity) harms residents' mental and physical conditions. Since $18^{\text {th }}$ century, simultaneous with the Industrial Revolution and the invasion of the crowd of jobseekers from rural parts to cities, an issue called housing has shown off (Shavay, 1996, p. 184). Many efforts has been done in this regard; however, $20 \%$ of the world population are lacking in favorable housing (Sarrafi, 2002, p. 5).

Estimations of United Nations Human Settlements Program: UN-Habitat, this issue indicates the unfavorable residential conditions. According to this estimation, one third of 3 billion residents of cities live in slums or in places where at least suffer from one of these characteristics: insecurity of lien, housing abnormal structural conditions and over-density. Housing allocate about 15 to 40 percent of monthly costs of households all over the world to itself and investment in housing market includes 15 to 35 percent of all investments in the world. Housing construction and sections related to it allocate about 9 percent of all world employment to itself (Athari \& Jawaheripoor. 2004, p. 38).

According to the World Health Organization, housing is the most important environmental factor related to disease conditions and life expectancy, and also it is considered as one of the most important indices of development physically (Rafiei, 2004, p. 134). Housing section has always been considered as a key economic 
urban section. Investing in this section constitutes 2 to 8 percent of GDP and 3 to 10 percent of gross capital formation in developing countries. On the other hand, housing is highly important as a property and constitutes 20 to 50 percent of productive wealth of countries (Azizi, 2004, p. 33). In developed countries, housing is considered as a dimension of social welfare and housing planning is focused on qualitative improvement. (Rafiei, 2000 , p. 4) But in developing countries, insufficient resources, economic management weakness, lacking in national comprehensive planning and increasing population have made providing housing in these countries complicated and multidimensional

\subsection{Importance of Housing}

Iran's population increase and the expansion of the range of urbanization during recent decades have caused centralization and increase in population densities in Iran's cities and this factor, besides increase in housing demands, has resulted in expensiveness of land prices and increase in building density particularly in big cities (Shi'e, 2005, p. 365). Accordingly, nowadays, housing has the highest cost in the urban households spending basket and households encounter many problems for providing housing in cities of Iran particularly big ones without other financial supportive resources such as inheritance. In this arena, low-income households have more difficulties particularly because they are neglected in most of national and local programs (Hatami Nejad, Seifoddini, \& Mireh, , 2006, p. 130). Regarding the 90 percent domination of non-governmental section in providing housing and the lack of efficient presence of the government in governance and ownership of housing market, this "market defeat" has had a powerful effect on occurring problems of housing section. (Bardi, \& Moradnejad, 2009, p.41)

Regarding the above mentioned discussions, housing planning is a vital and important issue.

\subsection{Integrated Urban Management}

\subsubsection{The Concept of Urban Management}

Stern considers urban management as a multidimensional concept which is indefinable; what is important is that he takes urban management as an integrated concept and believes that urban management necessitates an urban integrated approach to urban issues in developing countries. In many of these countries, the intervention of local government is limited to domain division policies and it restricts itself to only some of the minimum standards (Saeidi, 2008, p. 77). Urban management is an instrument by which the government can engender participatory and sustainable development.

Urban management was proposed firstly in 80's in developing counties and so far it has included three accepted concepts: first; urban officials are basically responsible for the affairs which occur in the cities. Second; the job of other urban mangers is not just to criticize higher levels of government because of not providing urban services, eliminating urban issues and problems and asking budget from them, but their urban managers are now responsible for preparing strategies, increasing investments and executing strategies and third; other comprehensive plan is not the most important tool for planning and in urban management, the relationships among urban authorities and state institutions related to urban and zonal development are important Urban management can be defined as "local government management through planning, organizing, optimizing affairs, attracting public participation and etc. using relationship with state and governmental institutions".

The process of management covers five main tasks: planning, organizing, human resources management, leadership and control.

\subsubsection{Urban Management Structure}

Objectives: the main objective of urban management is to organize urban affairs with public participation in order to provide citizens' public satisfaction; however, there are other objectives:

1) to organize urban sustainable development; 2) to promote and improve citizens' life conditions; 3 ) to protect urban environment; 4) to protect and improve urban body; and 5) to attract public participation in urban management.

Urban management tasks: any management requires knowing its authority scope and consequently tasks which should be considered; therefore, the main tasks of urban management are as follows: 1) urban planning; 2) construction activities; 3) service activities; 4) hygienic activities; 5) socio-cultural activities; and 6) protecting urban environment (Tabrizi, 2000, p.136).

Challenges and problems of urban management: urban management is a comprehensive concept and its objective is to reinforce public and un-public organizations to identify different plans and policies and executing them for achieving optimum results. Therefore, the efficient reaction to challenges and problems of cities and 
citizens with an active approach is considered the next challenge of urban management (Shabbir, 2000). Bourgeois and Castells describe 5 challenges encountered by urban management as follows:

1) To create economic foundation for cities and citizens; 2) To create urban infrastructures; 3) To improve citizens' life quality; 4) To guarantee citizens' social interestedness; 5) To provide and guarantee urban rules.

The quality of urban management is not only dependent on how to deal with these challenges but also it is related to creating integrity in urban development (Barakpoor \& Asadi. 2009).

Other challenges present in urban management system is "dispersion"; in other words, cities and urban zones are very complicated and dynamic physical, economic, political, social and cultural systems whose planned control and guide is faced with difficulties; therefore, it seems that the frequency of the different elements and dimensions of cities and citizens' lives on the one hand and multiple factors policy making and decision making in the development of cities and citizens' lives on the other hand are considered as potential threats for integrated planning and management.

\subsubsection{Comprehensive and Integrated Urban Management and with the Responsibility of Municipalities}

In the discussion of managing cities in Iran, what managers and authorities believe is not having a any organization responsible for managing urban affairs and citizens. Bewilderment in providing requirements and solving problems of citizens, revising regularly in urban projects, parallel workings and reworking continuously observed in cities are among the signs of lack of coordination among different organizations.

The intervention of 30 ministries and state organizations in urban affairs and not transferring 23 tasks of the government to municipalities which is codified in the Third Development Plan have caused that multiple management shadows the cities and hinders creating a comprehensive and integrated urban management. The intervention of these state institutions and organizations in urban management affairs, have force councils and municipalities to surrender the decisions of these organizations which are made outside the councils; therefore, they lose their real independence in the domain of cities. In governmental system of Iran, municipalities have no specified status while their jobs are public, cumbersome and difficult.

Comprehensive and integrated urban management is a concept which is considered as highly important in western counties, a concept by which these countries have been able to solve many problems of urban domains and citizens.

Ronald McGill in his article titled as "urban management in developing countries" answering the question "is urban management is an operational objective, process or a general structure?" regarding structural coordination refers to three key dimensions as constructive components of urban planning presented in three questions as follows:

First: it should be clarified that who or what should be the driving force of comprehensive and integrated urban management?

Second: it should be clarified that whether inherent complicatedness of urban system is resistant against comprehensive management? To do so, an approach compatible with the complicated organizational nature should be redefined.

Third: the potential contradiction and conflict among strategic forces and branches in the scale of cities and operational vividness in the level of project-which McGill calls it separation of planning from executing- should be resolved in a satisfactory way.

McGill believes that urban management in its approach to cities is conceptually holistic. This holism requires that the urban issues and problems be presented in the form of organizational and institutional questions and it means the unitary and integrated structure of urban management.

It seems that considering three following domains are the grounds of forming comprehensive and integrated urban management:

- Coordinating urban planning

- Coordinating providing infrastructures

- Coordinating institutions

In the meantime, a leading central force is required which be responsible for coordinating necessarily inter-organizational planning and budgeting. In its ideal form, this leading and coordinating force should be at the service of non-centralized executive level of the government, i.e. local government or urban government. Therefore, local government or municipalities are considered as the major driving forces for coordinating all 
players of the process of urbanization. By coordinating all players by an institution, processes and issues can be resolve and led. The requirement of all these issues, regarding the mentioned discussions, is revision in the relationship between municipalities, central governments, remained institutions and present regulations. In other words, in this process, the existence of a strategy of urban integrated management which focuses on both cities and institutional challenges and motivates the inter-sectional issues and consequently interventions and guarantees the direct relationship between planning and executing is necessary.

Citing the Article 3 of the Law on Municipalities and also the act of the list of non-governmental and public organizations and institutions approved on July 10, 1994 in the Parliament, municipality is an institution which is independent, public and non-governmental which according to laws and regulations, it should work under the Islamic city councils

Regarding the tasks and challenges of urban management, it is suggested that instead of transferring affairs to municipalities, the issue of observation of integrated urban management be adopted in Plan Act V based on which all related executive and service systems in urban domain are obliged to treat for the sake of urban management and do their activities in the framework and scope of cities in coordination with municipalities as" Higher Coordinating Director" and Islamic city council as "Supreme Supervisor of Affairs" (jamalinejad \& Zarrabi, 2010, p. 237).

\subsection{State Hypotheses and Objectives}

\subsubsection{Hypothesis of Research}

Is it possible to control the unbridled freedom of the housing and land market by presenting a systematic structure of integrated management in the housing market?

\subsubsection{General Objective:}

Investigating the process of open housing market and providing strategies after the Islamic revolution.

\subsubsection{Minor Objectives}

- To suggest strategies for preventing housing speculation, deteriorating dealing and hoarding with the approach of complete deletion

- To identify different state and urban organizations related to organizing open housing market and defining tasks for them

- To suggest the organizational chart as strategies in the form of new administrative syndicates for organizing open housing market.

\section{Method}

The conducted research in this article is based on the second type objective, i.e. applied research which is in the line with promoting life quality and welfare of people and in terms of nature and method, it is a causal research whose results are used for preventing unfavorable events. In this research, firstly the challenges of housing issue is investigated and then regarding library research, interviews and consultation with state authorities and elites of the housing market and also scientific and executive experience of the researchers, an organizational structure is proposed for fighting housing challenges. Then, by regulating questionnaires and surveying three groups (citizens, state and municipality authorities-academic specialists) this structure with matrix QSPM and SWOT model are evaluated. The first group are selected from citizens randomly but the second and third groups are selected among the academic professors and specialist related to urban issues and executive planners of municipalities. Finally, regarding the conducted surveys, strategies for improving the performance of proposed organizational structure are presented.

\subsection{Describe Suggested Organizational Structure for Urban Housing Planning with the Approach of Integrated Urban Management}

Regarding the mentioned discussions, urban housing planning is a vital and necessary issue which requires a comprehensive and integrated urban management. Concerning this important issue, in the following, the modern structural project of planning and control of urban housing prices with creating coordination between municipalities and city council is presented. The prerequisite for this project is establishing coordination among municipalities, city councils and other state organizations and of course on the responsibility of municipalities.

The suggested project investigate planning and controlling the housing market using important tools such as IT, which requires a comprehensive management and integrated interrelations between municipalities, city councils, state organizations such as the Real Estates Registration Organization and Tax Affairs Administration. The tax 
pressure lever is important in this section.

The offices on the responsibility of municipalities start to work by the help of private section and by supervision of city council. In the following, we discuss the structural chart and details of these offices.

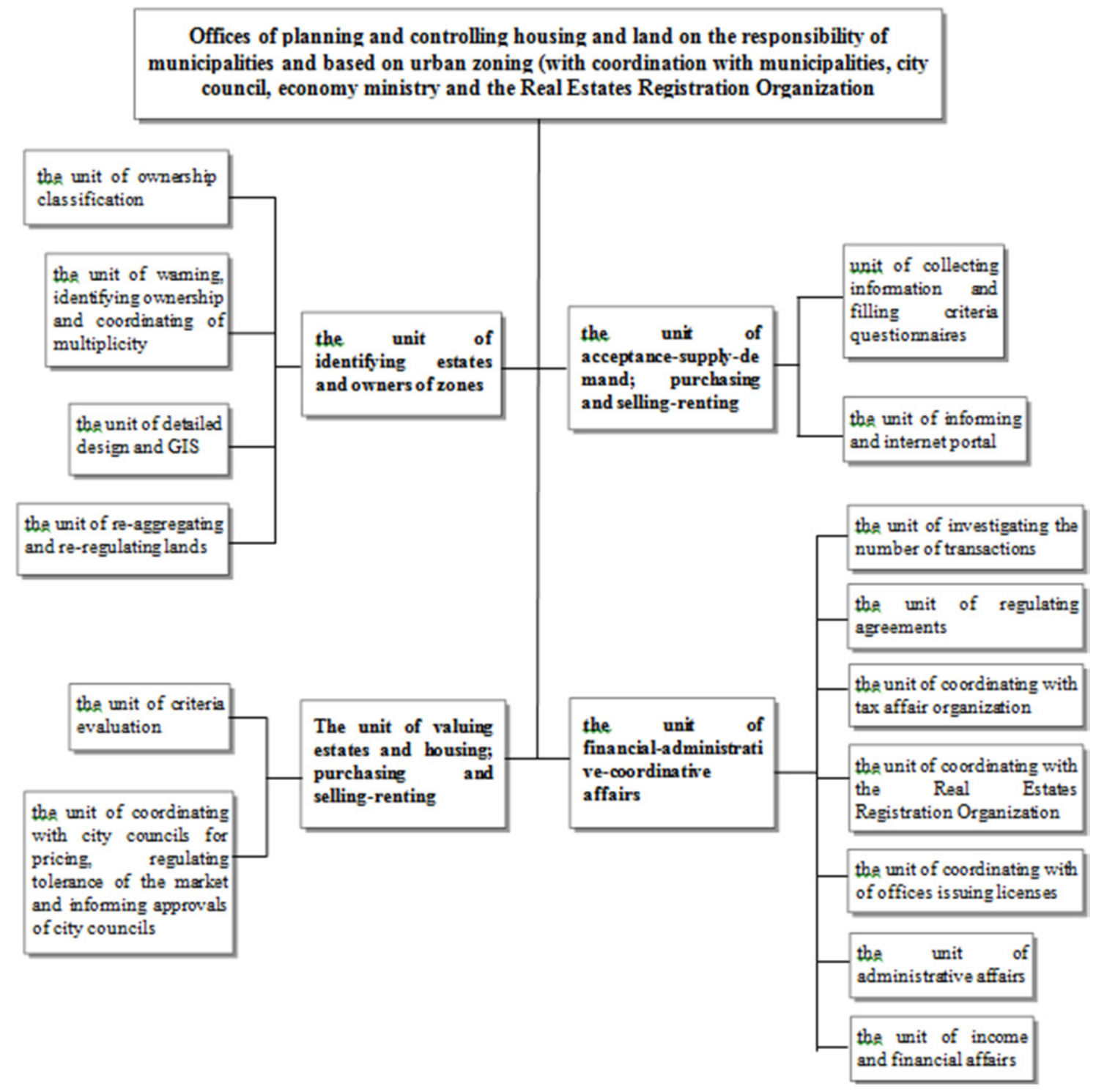

Figure 1. Organizational Chart of Offices of planning and controlling housing and land

\subsubsection{Explaining the Unit of Identifying Estates and Owners of Zones}

- The unit of identifying estates and owners of the zone $>>>$ the unit of classification of ownership

- Housing resided by owners

- Housing resided by tenants

- Housing unoccupied

- Unused estates and lands

- $\quad$ introductory sheets of housing cooperatives and private section for investing,

- $\quad$ referring for issuing licenses

- Using tax regulations

This unit with ownership classification helps authorities for adopting appropriate policies, for example by 
housing tax offs based on rental rates we can motivate owners to get less rental. Among the strategic policies adopted by governments to regulate housing and land market is using tax leverage. The experiences of other countries show the control of housing and land prices due to adopting tax policies, although adoption of tax policies should be based on local conditions. Getting heavy taxes from the owners of unused lands required by urban development and unoccupied houses can reduce speculation and soaring prices in these zones and by preventing unproductive speculation and brokerage moves the investments towards production and increase in employment. Taxation is the double-edged sword which even when is in the scabbard, it has preventing effect as well. Such a regulation is true for taxation of housing market, the double-edged sword for motivating productive investment and for avoidance from deteriorating investment.

- The unit of identifying estates and owners of the zone $>>>$ unit of warning, identifying the multiplicity of ownership and integration

As mentioned in the case of the unit of ownership classification, in some cases, the real estate available in the city encounters uselessness (speculation) and consequently the concept of ownership multiplicity. Ownership multiplicity is one of the most important reasons of housing challenge and lack of paying attention to this issue causes inflation of housing prices and increase in class gaps. This unit, by the help of ownership classification identifies mentioned estates and informs the owners the required warnings and in case of lack of responding appropriately, the issues are reported to Tax Affairs Organization, Real Estate Registration Organization and other related institutions. Regarding the type of the adopted policy in case of the useless real estates which both has causes the backwardness of the interurban development and increase in the prices of housing market, this unit conducts the required integrations for communications with the resources of issuing licenses, housing cooperatives and the investing private sectors, Tax Organization, the Real Estate Registration Organization and etc.

- The unit of identifying estates and owners of the zone $>>>$ the unit of detailed design and GIS

The detailed design is a design which determines, based on the general criteria and regulations of the comprehensive design, the mode of sung urban lands in the levels of the different urban neighborhoods based on the location and the exact area of lands, the exact and detailed states of transporting networks, the mount of population density, the priorities related to optimization affairs, development and resolution of urban problems and the situation all different urban factors. The detailed design in fact is regulating a detailed plan and executing part-to-part measures in urban zones and neighborhoods and their designs.

To use GIS in housing planning, there are two kinds of activities:

1. Investigating the status quo using qualitative and quantitative housing indices such as pure and impure density, being newly-constructed or worn-out, being semi-destructive of the state of zones' housing. Following this issue, first of all, the desired scope should be identified and its residential user map and descriptive data or descriptive tables should be prepared.

2. Futurism and suggestions: after preparing the status quo information, in more advanced section, using housing planning and predicting models, the required planning will be done for the future.

- The unit of identifying estates and owners of the zones $\gg>>$ the unit of re-aggregating and re-regulating lands

The main idea of the method of re-aggregating and re-regulating lands is the changes of land division and this means that in this method, there is no need to ownership and seizing lands from the institution responsible for the project (municipality) or investors; therefore, there is no paying the intermediate cost and the danger of transferring constructed lands to the private sector. This method, contrary to the common methods on the plan of urban planning such as compulsory purchase of land from the owners or the dispossession of ownership from them acts for developing the plan's objectives. Adopting this unit in planning offices particularly the field of the interurban worn-out and unstable texture seems necessary.

\subsubsection{Explaining the Unit of Valuing the Estates and Housing (Purchasing and Selling-Renting)}

One of the tasks of councils is to investigate and identify the social, cultural, educational, health, economic and welfare deprivations, requirements and deficits of their zones and preparing amended plans and suggestions and applied strategies in these fields for planning and providing them for related authorities, which the issue of housing is prioritized for investigation concerning future challenges. Regarding the Islamic basics of the project, the city councils should do the required measures for rating housing in different zones of the city and concerning the frequencies of the market, determine the tolerance of prices in the market.

It should be noted that codification of agendas and regulations of other units in planning offices should be 
approved by councils before being executed.

- The unit of valuing estates and housing (purchasing and selling-renting) $\gg>>$ the unit of criteria evaluation

- The criteria zones, neighborhoods and neighbors

- the number of units and floors in a complex

- the number of units in a floor

- the quality of neighborhoods

- passages and accesses

- the class quality of cities' zones

- access to trade

- educational and public services centers

- Quantitative -physical criteria

- land's area

- infrastructure's area

- the number of rooms

- the type of construction

- WCs and surplus numbers

- the type of kitchens

- the quality of cabinet and decorations

- heating and cooling facilities, the number of parking

- $\quad$ surplus welfare facilities and users

- Qualitative criteria of buildings

- Architectural Design

- oldness of buildings

- being apartment or villa

- the quality of construction

- desired floor, location

- $\quad$ skylight and landscapes

This unit is prerequisite for the unit of acceptance, supply-demand (the unit of collecting information and filling the questionnaire of criteria evaluation) and for codification of the nature of the questionnaires, deep scientific-field research and market elites are required.

- the unit of valuing estates and housing (purchasing and selling-renting) >>>the unit of coordinating with city councils for pricing, regulating tolerance of the market and informing approvals of city councils

City Council should consider the degree to pricing of housing in different parts of the city, take action and determine the market price due to market volatility tolerance.

\subsubsection{Explaining the unit of Acceptance-Supply-Demand (Purchasing and Selling-Renting)}

- The unit of acceptance-supply-demand (purchasing and selling-renting) $>>>$ the unit of informing and internet portal

In this unit, information and images collected from estates for supplying are available for the public through internet portal regarding questionnaires of criteria evaluation. This portal, with an information spatial planning classifies the houses for supply regarding the indices of price, area, zone and etc. and the guides the demander in selecting the desired alternative regarding his purchase power and taste.

The demanders, after investigating all related characteristics and images and in case of desirability, refer to the desired office (which is referred to in its number and feature) for visiting personally (finally) and regulating the agreement.

- The unit of acceptance-supply-demand (purchasing and selling-renting) $>>>$ the unit of collecting information 
and filling questionnaires of criteria evaluation

In this unit, the questionnaires of criteria evaluation provided in the field of evaluating criteria are used.

After the visiting of citizens to the office for conducting housing transactions (purchasing and selling-renting), the specialized forces refer to the desired estate by the permission of the owners and by taking images (photos and films) and also filling the questionnaires of criteria evaluation, provide the required information for putting in the internet portal and publicize it in the virtual space.

\subsubsection{Explaining the unit of Financial-Administrative- Coordinative Affairs}

The unit of financial-administrative- coordinative affairs

- the unit of investigating the number of transactions

- the unit of regulating agreements

- the unit of coordinating with tax affair organization

- the unit of coordinating with the Real Estates Registration Organization

- the unit of coordinating with of offices issuing licenses

- the unit of administrative affairs

- the unit of income and financial affairs

The requirement for success of this plan is to pass all stages if housing transactions(purchasing and selling-renting) and complementing this process from the channel if these offices; therefore, coordinating these offices with all departments and organizations related to housing transferences and transactions like the Real Estate Registration Organization and cases as such are necessary. For example, if an estate does not have any approved file in these offices, any document should not be transferred in the Real Estate Registration Organization.

In this unit, the regularity of transactions is observed and if necessary, tax leverages are adopted. Moreover, in this unit, the required coordination with the offices issuing licenses (particularly regarding useless lands in cities) are administered. Other functions of this unit is regulating agreements and financial and administrative affairs.

\subsection{Sampling Procedures}

The statistical population of the three groups (citizens, public authorities and municipalities, and academic experts in Islamic sciences) has been established.

The first group are selected from citizens randomly but the second and third groups are selected among the academic professors and specialist related to urban issues and executive planners of municipalities. Finally, regarding the conducted surveys, strategies for improving the performance of proposed organizational structure are presented

\subsubsection{Sample Size, Power, and Precision}

Citizens in the statistical population, the sample size based on Cochran formula is 378 , but experts in statistical population, due to the low volume of all completed questionnaires

\subsubsection{Confirm the Research Hypothesis}

To investigate the relationship between the integrated management of housing market and control of land and housing market, Pearson correlation test was used.

Confidence level of the test Equal to 0 and less than $1 \%$. As a result, the relationship between these two variables there is a significant probability of $99 \%$. The correlation of $(0.826)$ indicates a direct and positive relationship between the two variables. As a result, the research hypothesis is confirmed.

Table 1. Pearson correlation analysis

\begin{tabular}{lccc}
\hline & Total capital stock & $\begin{array}{c}\text { Integrated } \\
\text { management of the } \\
\text { housing market }\end{array}$ & $\begin{array}{c}\text { Control of land and } \\
\text { housing market }\end{array}$ \\
\hline $\begin{array}{l}\text { Integrated } \\
\text { management of the } \\
\text { housing market }\end{array}$ & $\begin{array}{c}\text { Pearson correlation } \\
\text { Confidence level } \\
\text { Numbers }\end{array}$ & 1 & $.826^{* *}$ \\
& & 378 & .000 \\
\end{tabular}




\begin{tabular}{llcc} 
Control of land and & Pearson correlation & $.826^{* *}$ & 1 \\
housing market & Confidence level & .000 & \\
& Numbers & 355 & 355 \\
\hline
\end{tabular}

\section{Results}

In this research, firstly the challenges of housing issue is investigated and then regarding library research, interviews and consultation with state authorities and elites of the housing market and also scientific and executive experience of the researchers, an organizational structure is proposed for fighting housing challenges. Then, by regulating questionnaires and surveying three groups (citizens, state and municipality authorities-academic specialists) this structure with matrix QSPM and SWOT model are evaluated. The first group are selected from citizens randomly but the second and third groups are selected among the academic professors and specialist related to urban issues and executive planners of municipalities. Finally, regarding the conducted surveys, strategies for improving the performance of proposed organizational structure are presented.

\subsection{Quantitative Strategic Planning Matrix (QSPM)}

Quantitative strategic planning matrix (QSPM) is an analytical method by which the relative attraction of strategies are identified. When applying the Quantitative strategic planning matrix (QSPM), the intuitive judgment should be used as appropriately as possible.

Regarding the weaknesses and strengths and also threats and opportunities, the mentioned matrix in two domains of internal factors (IFE) and external factors (EFE) were formed. As mentioned, in the surveys, the ideas of three groups (citizens, state and municipality authorities-academic specialists) were used and the total of the scores of these three groups were used for analysis. Then, after regulating and investigating matrix QSPM, to codification of required strategies, the following chart was used. Regarding the grid graph, if the situation of the organization in terms of the scores of external and internal factors is in I, the revision strategy (conservative) in II, offensive strategy (growth and development) in III and defensive strategy in IV, the diversity strategy is advised. Of course, these strategies are combinational, but the focus is more on any strategy is based on the final situation of matrix in the chart.

External factor

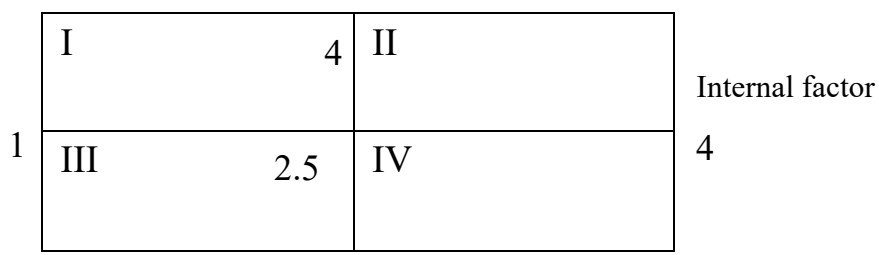

Figure 2. Zones of strategies

\subsubsection{Analyzing Internal Factors ( $\mathrm{S}=$ Strengths; $\mathrm{W}=$ Weaknesses)}

$\mathrm{S} 1=$ clarifying the housing market and reducing anarchy in the market

$\mathrm{S} 2=$ systematizing housing pricing

S3=informing the full-time supply and demand with high security and efficacy

S4=preventing from speculation and hoarding in the housing and land market

$\mathrm{S} 5=$ determining the qualitative, quantitative and physical indices in housing pricing

S6=increasing effective housing demand (housing demand only for having shelter not for investment)

$\mathrm{S} 7=$ reducing housing and land prices by increasing supply of estates and hoarded houses

S8=establishing and actualizing housing and land prices by city councils

S9= Adopting e-government services for promoting cooperation between organizations with the management of municipalities

S10=identifying estates and owners of the zones and regularity of transactions for strategic and tax planning

S11=creating cooperation between owners for re-accumulation and re-regulation of lands 
S12=encountering citizens with a unitary system for doing transactions of ones' houses

S13=promoting information cooperation of housing transactions with the detailed design

$\mathrm{W} 1=$ economic stagnation of the union real estate agencies

W2=limiting economic freedom of the housing market

$\mathrm{W} 3=$ construction stagnation due to actualizing prices and reducing benefits for constructors

W4=decreasing economic self-confidence of households and reducing housing prices

3.1.2 Analyzing external factors $(\mathrm{O}=$ opportunities; $\mathrm{T}=$ threats $)$

$\mathrm{O} 1=$ preventing from fake inflation in the housing market

$\mathrm{O} 2=$ preventing from fake liquidity in Iran's economy

$\mathrm{O} 3=$ reducing the gap between social classes and social issues related to them

O4=reducing investing housing demand and guiding capitals to effective production

$05=$ increasing farming lands by reducing speculation and hoarding the farming lands around cities

O6= developing e-city and providing e-services for citizens

$\mathrm{O} 7=$ creating models for promoting comprehensive and integrated management in other fields

$\mathrm{O} 8=$ increasing tax incomes in households' cost baskets and increasing medical, educational and entertaining standards

$\mathrm{O} 10=$ deleting misuses of opportunists and hoarders of housing and land markets

O11=deleting fake incomes of housing and land transactions

O12=reducing farming and industrial lands' prices by reducing speculations and hoarding and contributing to agricultural and industrial economy

$\mathrm{T} 1=$ reducing employment in jobs related to housing section

$\mathrm{T} 2=$ escaping capitals available in housing section to abroad

$\mathrm{T} 3=$ weakening industries related to construction industry by stagnation of the housing market

$\mathrm{T} 4=$ reducing state capitals which are dependent on real estates the government and municipalities by reducing estates' prices

Table 2. Analyzing internal factors of QSPM

\begin{tabular}{|c|c|c|c|c|c|c|c|c|c|}
\hline \multirow[t]{3}{*}{$\begin{array}{l}\text { Analyzing internal } \\
\text { factors }\end{array}$} & \multicolumn{4}{|c|}{ academic specialists } & \multicolumn{3}{|c|}{$\begin{array}{c}\text { state and } \\
\text { municipality authorities }\end{array}$} & \multicolumn{2}{|c|}{ Citizens } \\
\hline & \multicolumn{9}{|c|}{ rior finasignificant coefficientveightrioriț̣inahnlignificant coefficienveightrioriț̣finaanlignificant coefficienveight } \\
\hline & sco & & mear & & scor & & mean & scor & mean \\
\hline S1 & 10.294 & 0.07 & 3.85 & 1 & 0.314 & 0.077 & 3.613 & 0.244 & 0.062 .72 \\
\hline S2 & 20.284 & 0.07 & 3.71 & 3 & 0.294 & 0.071 & $3.33 \quad 4$ & 0.244 & 0.062 .64 \\
\hline S3 & 30.213 & 0.07 & 3.64 & 4 & 0.23 & 0.067 & $3.14 \quad 1$ & 0.23 & 0.072 .94 \\
\hline S4 & $\begin{array}{ll}5 & 0.23\end{array}$ & 0.07 & 3.57 & 2 & 0.223 & 0.074 & $3.44 \quad 9$ & 0.153 & $0.05 \quad 2.2$ \\
\hline S5 & 70.244 & 0.06 & 3.21 & 7 & 0.254 & 0.061 & 2.867 .5 & 0.214 & 0.052 .34 \\
\hline S6 & 100.23 & 0.07 & 3.48 & 10 & 0.193 & 0.065 & $3.03 \quad 10$ & 0.23 & 0.072 .92 \\
\hline S7 & 40.274 & 0.07 & 3.6 & 9 & 0.24 & 0.05 & 2.337 .5 & 0.214 & 0.052 .34 \\
\hline S8 & 90.244 & 0.06 & 3.16 & 6 & 0.244 & 0.061 & $2.84 \quad 5$ & 0.234 & 0.062 .52 \\
\hline S9 & 120.173 & 0.06 & 3.03 & 11 & 0.143 & 0.047 & 2.2112 .5 & 0.153 & 0.052 .18 \\
\hline $\mathrm{S} 10$ & 80.234 & 0.06 & 3.09 & 8 & 0.234 & 0.058 & $2.69 \quad 6$ & 0.224 & 0.052 .43 \\
\hline S11 & 130.153 & 0.05 & 2.67 & 12 & 0.143 & 0.048 & 2.2512 .5 & 0.143 & 0.052 .13 \\
\hline $\mathrm{S} 12$ & $6 \quad 0.23$ & 0.07 & 3.53 & 5 & 0.193 & 0.063 & $2.95 \quad 2$ & 0.193 & 0.062 .81 \\
\hline
\end{tabular}




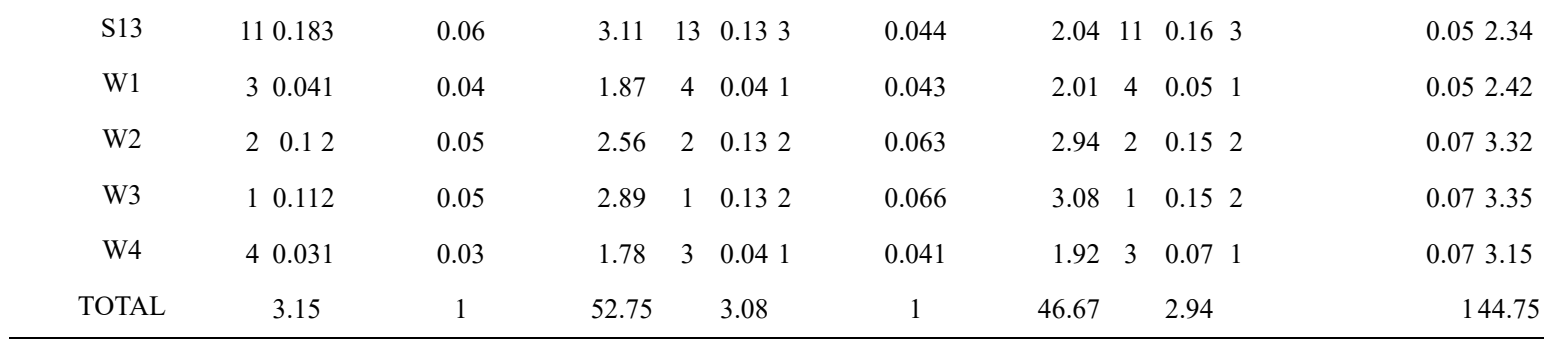

Table 3. Analyzing external factors of QSPM

\begin{tabular}{|c|c|c|c|c|c|c|c|c|c|c|}
\hline \multirow[t]{3}{*}{$\begin{array}{c}\text { Analyzing externa } \\
\text { factors }\end{array}$} & \multicolumn{4}{|c|}{ academic specialists } & \multicolumn{3}{|c|}{$\begin{array}{c}\text { state and } \\
\text { municipality authorities }\end{array}$} & \multicolumn{3}{|c|}{ Citizens } \\
\hline & \multicolumn{10}{|c|}{ efficientveightrioriț̣inalanlignificant coefficienveightrioriț finahnlignificant coeffi } \\
\hline & scol & & mear & & scori & & mean & & scori & mean \\
\hline O1 & 10.294 & 0.07 & 3.71 & 1 & 0.274 & 0.07 & 3.54 & 3 & 0.184 & 0.062 .72 \\
\hline $\mathrm{O} 2$ & 50.274 & 0.07 & 3.52 & 6 & 0.244 & 0.06 & 3.21 & 7 & 0.124 & 0.052 .28 \\
\hline $\mathrm{O} 3$ & 30.284 & 0.07 & 3.61 & 3 & 0.264 & 0.06 & 3.42 & 2 & 0.194 & 0.072 .84 \\
\hline $\mathrm{O} 4$ & 60.264 & 0.07 & 3.38 & 5 & 0.254 & 0.06 & 3.25 & 6 & 0.164 & 0.062 .57 \\
\hline $\mathrm{O} 5$ & 70.254 & 0.06 & 3.24 & 2 & 0.264 & 0.07 & 3.47 & 4 & 0.174 & 0.062 .65 \\
\hline O6 & 120.183 & 0.06 & 3.11 & 12 & 0.173 & 0.06 & 3.07 & 11 & 0.113 & 0.052 .18 \\
\hline $\mathrm{O} 7$ & 110.183 & 0.06 & 3.15 & 11 & 0.183 & 0.06 & 3.22 & 12 & 0.13 & 0.052 .02 \\
\hline $\mathrm{O} 8$ & 90.193 & 0.06 & 3.29 & 9 & 0.23 & 0.07 & 3.58 & 10 & 0.163 & 0.062 .61 \\
\hline O9 & 20.294 & 0.07 & 3.66 & 4 & 0.254 & 0.06 & 3.36 & 1 & 0.244 & 0.073 .17 \\
\hline $\mathrm{O} 10$ & 80.23 & 0.07 & 3.44 & 8 & 0.213 & 0.07 & 3.73 & 8 & 0.213 & 0.072 .96 \\
\hline O11 & 100.193 & 0.06 & 3.2 & 10 & 0.23 & 0.07 & 3.56 & 9 & 0.163 & 0.062 .64 \\
\hline $\mathrm{O} 12$ & 40.274 & 0.07 & 3.44 & 7 & 0.234 & 0.06 & 3.11 & 5 & 0.164 & 0.062 .58 \\
\hline $\mathrm{T} 1$ & 10.112 & 0.06 & 2.91 & 1 & 0.122 & 0.06 & 3.21 & 1 & 0.232 & 0.073 .14 \\
\hline $\mathrm{T} 2$ & 30.051 & 0.05 & 2.45 & 3 & 0.061 & 0.06 & 3.09 & 3 & 0.171 & 0.062 .67 \\
\hline $\mathrm{T} 3$ & 40.051 & 0.05 & 2.35 & 4 & 0.051 & 0.05 & 2.87 & 2 & 0.191 & 0.072 .82 \\
\hline $\mathrm{T} 4$ & 20.061 & 0.06 & 2.89 & 2 & 0.061 & 0.06 & 3.34 & 4 & 0.141 & 0.062 .42 \\
\hline TOTAL & 3.12 & 1 & 51.35 & & 3.03 & 1 & 53.03 & & 2.68 & 142.27 \\
\hline
\end{tabular}

\subsection{SWOT Analytical Model}

This model is one of the important tools by which managers compare information and can present it in four kinds of strategies:

\begin{tabular}{|l|l|l|}
\hline & Strengths $=\mathbf{S}$ & weaknesses $=\mathbf{W}$ \\
\hline Opportunities $=\mathbf{O}$ & SO strategies & WO strategies \\
\hline Threats $=\mathbf{T}$ & ST strategies & WT strategies \\
\hline
\end{tabular}

Figure 3. SWOT strategies

(Fred R. 1999: 364)

\section{Discussion}

\subsection{Codifying Strategies}

As illustrated in the chart, the final total score in the internal factors and external factors domain and in the three mentioned groups, the survey indicates a favorable situation (the mean is above 2.5) and this issue indicates this point that the proposed plan is desired by the population.

Regarding the investigation of the matrices QSPM and the proposed chart of suggested strategies are more tended to offensive aspects (development). 


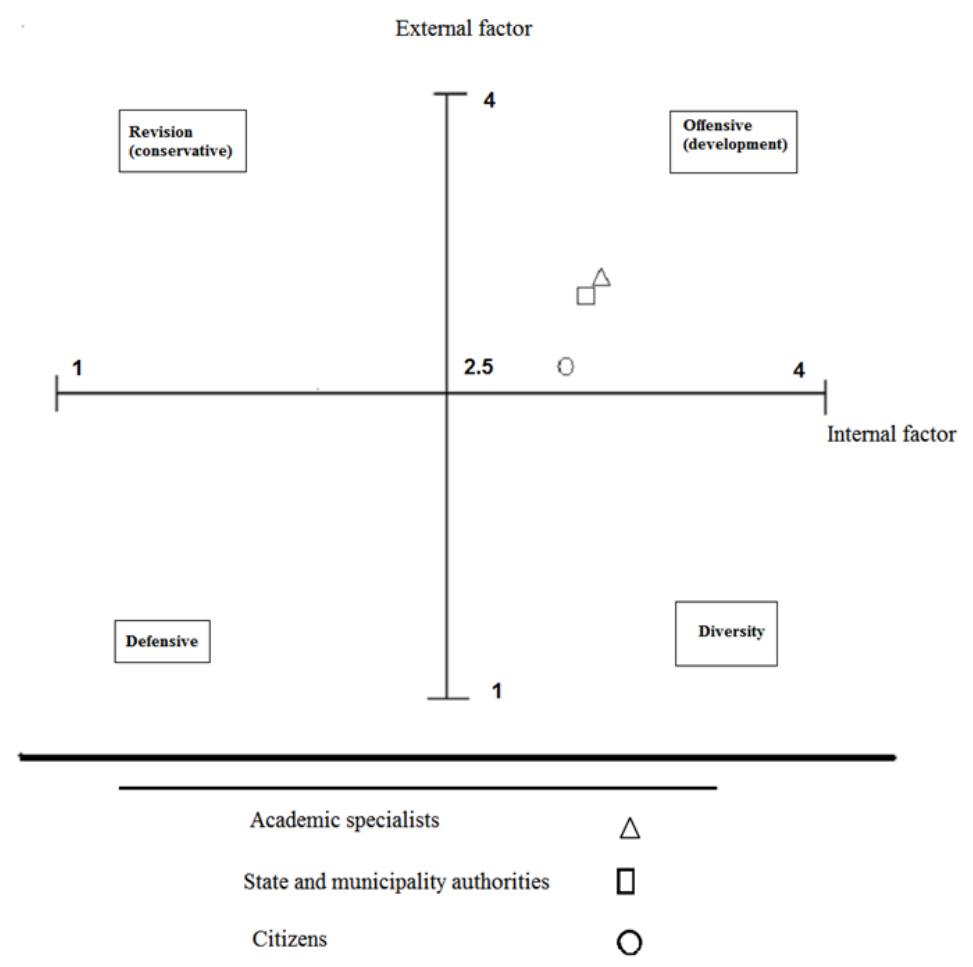

Figure 4. zones of strategies of statistical population

\subsubsection{SO Strategies}

1. facilitating the codification of regulations related to urban housing planning regarding economic pressure on the middle and lower classes of the society (extracted from: S1, S2, S3, S4, S7, S8, O1, O3, O4, O9, O10)

2. Promoting the coordination of ICT organization with municipalities and city council for setting out these offices and codification of related regulations (extracted from: S3, S9, S12, S13, O6, O7)

3. Constructing a technical committee for determining the quantitative-qualitative and physical indices by academic specialists, state authorities and elites of the union real estate agencies for pricing housing truly (extracted from: S3, S9, S12, S13, O6, O7)

4. Codifying related regulations for effective use of housing instead of the investing use (extracted from: S6, S7, S8, S10, O3, O4, O5, O8, O12)

5. Codifying regulations related to integrated and comprehensive management for housing planning with the responsibility of municipalities and strategic coordination of city councils (extracted form: S2, S3, S9, S11, S12, S13, O6, O7).

6. Developing housing cooperatives and encouraging housing mass constructors for guiding distracted capitals in the housing market with the direct supervision of the government (extracted from: S2, S13, O6, 07)

7. Codifying intelligent system and developing E-network in the line with institutionalizing and promoting E-housing markets (extracted from: S2, S3, S9, S12, O6, O7)

8. Designing a systematic structure for reducing corruption in the housing market and the great incomes to a specific job or a particular class of the society (extracted from: S1, S3, S8, S10, O1, O4, O10, O11)

9. Codifying an intelligent tax system in the housing market such a way that some of the fake incomes of this market be transferred to the state and the motivation of accumulation of liquidity reduces in this domain (extracted from: S4, S10, O1, O2, O8, O11)

10. Planning for guiding distracted and disappointed capitals from housing markets to industries, agriculture and effective production (extracted from: $\mathrm{S} 8, \mathrm{O} 4, \mathrm{O} 5, \mathrm{O} 12$ ) 
11. Designing and codifying a statistical system in the domain of owners and current transactions information in the line with clarifying the housing market (extracted from: S1, S10, O1, O4, O10)

12. Designing and codifying a comprehensive urbanization system for accumulation an regulating the available estates in the line with increasing the desired user efficiency of cities (extracted from: S4, S11, O4, O9)

\subsubsection{ST Strategies:}

1. Using the potential of worn-out textures for developing urban development using strategies such as reaccumulation and re-regulation of lands: extracted from: S9, S11, S13, T1, T3)

\subsubsection{WO Strategies}

1. Centralizing the union real estate agencies and getting help from this private sector for developing offices of housing planning (extracted from: W1, W2, O6, O7,O10, O11)

2. Acculturating media for preventing from psychological beneficial effects of housing markets and also acculturation for promoting production (extracted from: W4, O3, O4, O9, O12)

\subsubsection{WT Strategies}

1. Conducting studies and research on housing related to public culture of the society in defining the housing market and preventing from its unfavorable results on the society (extracted from: W2, W4)

2. Applying bank-financial policies for attracting surplus liquidity in the housing market and preventing from capitals exiting the country

3. Planning for reducing dependency of state institutions on reals estate under the ownership of the government for supplying the lack of required liquidity (extracted from: W2, T4)

4. Industrializing constructions and buildings and employing appropriately for reducing fake employments and promoting economic growth (extracted from: W3, T1, T3)

\section{Conclusion}

Housing is one of the most important and basic human requirements and has a basic role in supplying human welfare. Regarding the multidimensionality of the housing concept, for urban housing planning, the intervention of different state and urban organizations is required and the lack of a comprehensive and integrated management in this regard is felt. Regarding the mentioned discussions and issues, the researchers of the present study, first investigated the problem of housing and then regarding the library research, interviews and consulting with state authorities and elites of the housing markets and also the scientific and executive experiences of the researchers, proposed an organizational structure for fighting with the problem of housing. Then, by regulating questionnaires and surveying three groups (citizens, state and municipality authorities-academic specialists) this structure with matrix QSPM and SWOT model was evaluated. Finally, concerning the conducted surveys, five strategies in the domain SO, two in the domain ST, three in the domain WO and four in the domain WT for improving the performance of the proposed organizational structure were presented. By considering the tasks and challenges of urban management, it is suggested that instead of transferring affaires to municipalities, the issue of observation of the integrated urban management be adopted in the Fifth Plan Act and all executive and service systems related to urban domain be responsible for urban management and do their activities in the framework of cities with the coordination with municipalities as" Higher Coordinating Director" and Islamic city council as "Supreme Supervisor of Affairs".

In line with the research question and concerning the conducted surveys, municipalities and city councils can organize the problem of housing and its open market by applying proposed structure or a similar structure.

It is hoped that the present study can take an effective step toward promoting urban housing planning particularly in developing countries and guides the distracted investments from the open housing market towards nourishment of production ad industry.

\section{References}

Athari, K., \& Jawaheripoor, M. (2004). The research project of financial system for supplying housing for low-income class. Tehran: The Ministry of Housing and Urban Development. National Organization for Land and Housing.

Azizi, M. (2004). An analysis of status and upheavals of urban housing indices in Iran. Beautiful arts journal, 23, $31-45$. 
Barakpoor, N., \& Asadi, I. (2009). Urban management and governance. $1^{\text {st }}$ edition. Tehran: Art University.

Bardi, R., \& Moradnejad, A. (2009). An introduction to urban poverty by focusing on housing poverty in urban points of Iran's provinces. Journal of human geography, 3(1), 35-51.

Choay, F. (2009). Urbanization, Imaginations and Realities. (S.M. Habibi Trans.). Tehran: University of Tehran.

Fred, R. D. (1990/1998). Strategic management. (A. Parsaein \& M. Arabi, Trans.). Tehran: cultural research publications.

Hatami, N. H., Seifoddini, F., \& Mireh, M. (2006). Investigating the indices of informal housing in Iran; case study: Sheikh Abad neighborhood, Qom. Journal of geographical research, University of Tehran, 58, 15-139.

Jamalinejad, M., \& Zarrabi, A. (2010). Investigating the role of integrated urban management in observation of some of social security, case study: Isfahan province. Journal of Urban Management, 21, 2-19.

Patrick, J. M. (1999/ 1995). A dictionary of learning management knowledge. (S. Khalili Shourini Trans.), Tehran: Yadvareh publication.

Rafiei, M. (2000). Urban housing toward local planning. Municipalities Monthly Journal, 19, 2-17.

Rafiei, M. (2004). Housing right in Iran: policies for supplying housing for a particular group. Journal of housing economy, 35, 131-145. Tehran: National Organization for Land and Housing.

Saeidi, A. (2008). Encyclopedia of urban and rural management. Journal of Institute of Municipalities and Rural Municipality Administrators of Iran, 90, 75-80.

Sarrafi, M. (2002). From marginalization to urbanization; case study of seven cities. Journal of Construction and Urban Optimization, 8, 2-17.

Shabbir, J. Ch. (1995/2000). Urban management: policies and innovations in developing countries (P. Zahedi Trans.). Tehran: Urban planning and processing publication.

Shavay, F. (1996 ). Urbanity, imagination - facts. (S. M. Habibi Trans.), Tehran: Tehran University.

Shi'e, E. (2005). The crisis of new residential textures in Iran's big cities. Social Welfare Journal, 16, 360-374.

Tabrizi, J. (2000). Urban development management..) Urban Management Journal, 2, 133-147.

\section{Copyrights}

Copyright for this article is retained by the author(s), with first publication rights granted to the journal.

This is an open-access article distributed under the terms and conditions of the Creative Commons Attribution license (http://creativecommons.org/licenses/by/3.0/). 